\title{
PENERAPAN METODE ANALYTICAL HIERARCHY PROCESS (AHP) PADA SISTEM PENDUKUNG KEPUTUSAN PEMILIHAN LAPTOP
}

\author{
Eka Ridhawati, M.Kom ${ }^{1}$, Zulkifli, ST., M.Kom ${ }^{2,}$, Devi Yunita ${ }^{3}$ \\ ${ }^{1}$ Dosen Sistem Informasi , STMIK Pringsewu Lampung \\ ${ }^{1}$ Email : ekaridhawati@gmail.com \\ ${ }^{2}$ Dosen Sistem Informasi, STMIK Pringsewu Lampung \\ ${ }^{2}$ Email : zulkiflist31@gmail.com \\ ${ }^{3}$ Mahasiswa Jurusan Sistem Informasi, STMIK Pringsewu Lampung \\ ${ }^{3}$ E-mail: deviairen20@yahoo.com
}

\begin{abstract}
ABSTRAK
Proses pemilihan sebuah laptop harus didasarkan pada kemampuan dan kebutuhan pembeli. Ketika pembeli dihadapkan pada banyak pilihan merk laptop dan berbagai spesifikasinya. Dari hal tersebut dibuatlah sebuah sistem pendukung keputusan yang ditujukan untuk membantu pembeli memilih laptop yang sesuai dengan kriteria Style, Reability dan Price, serta mengambil alternatif Samsung, HP dan Lenovo. Penelitian ini memanfaatkan metode Analitical Hierarchy Process (AHP). Didapatkan hasil perengkingan Samsung, HP (Hewlett-Packard) dan Lenovo.
\end{abstract}

Kata Kunci : Laptop, Sistem Pendukung Keputusan, Analytical Hierarchy Process. 